\title{
常食栄養価計算方法の比較について
}

\author{
新潟市新潟. 病院

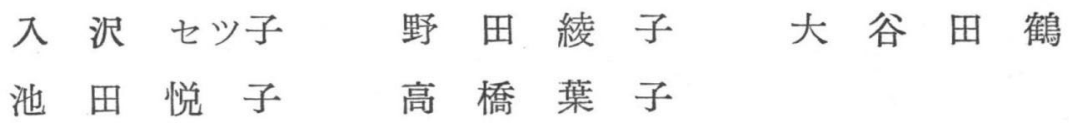

1. 緒 言 私たち病院栄養士は, 多種類の治 療食の献立および調理から, 入院, 外来患者に対す る栄養指導, その他いろいろの帳簿の整理など, そ の業務の複雑困難なるところから少しでも事務的手 数を省略したいのが実情である。

そこで今までにも給食事務の能率化, 簡素化のた め, 常食の栄養出納は荷重平均分析表によって, 栄 養価算定をやってきた。

ところが最近, 指導機関の方針も変わり個々の食 品別による栄養価計算方法を採用するようにとのこ とであり, 現に学校, その他の事業所においては, それを実施している。

また最近, 分析表が改正されても, 荷重平均分析 表は35年以後のものは発表されていない。

そこで私たち新潟市病院給食研究会でこの問題を 取りあげて，その第一段階として，常食栄養価の計 算方法を比較することになった。

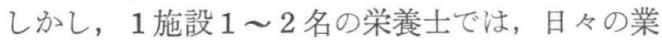
務に扮われなかなか実施できなかったが，たをたま 当病院で昨年の地震の災害復旧工事で病床数が半減 したのを利用して，2 2 月間次の方法で比較検討し て見た。

\section{2. 調查研究の方法}

対象：常食 期間： 40 年 6 月〜 7 月の 2 力月間

方法：(1) 2 力月間毎日食品別分析表による栄養計 算

(2) (1)をとにして, 食品群別に日計表を作 り，上旬，中旬，下旬の 10 日間ずつに合 計して荷重平均分析表で計算

\section{3. 成續および考察}

(1)の10日間の平均と比較した。

表 16 月上旬, 中旬, 下旬の 10 日間に分けて, 荷重平均と食品別分析表とを比較したもの

表2 7 月を表 1 と同じように比較したもの

表 3 表 1 , 表 2 によって, 1 力月の平均を出し て比較したもの

このように, 1 カ月の平均の数值では, 熱量, “蛋 白, 脂肪, 含水炭素においては目立った差はみとめ られなかった。

燐, 鉄, ビタミン $\mathrm{A}$ が 6 月, 7 月共に荷重平均の 方が多く,ビタミンCは 6 月のみ食品別に計算した 方が多くなっている。それが何に原因するか考え てみた。

まず, 6 月, 7 月の食糧構成を作って見たがいずれ の月も大差なく, 使用食品によるものと考兵られる。 表 4 : 食品別の使用量を見ると表 4 のような結果 が出た。

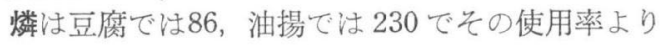

表 16

月

上旬

\begin{tabular}{|c|c|c|c|c|c|c|c|c|c|c|c|}
\hline & 熱 量 & 蛋白質 & 脂 肪 & 含水炭素| & $\begin{array}{l}\text { カルシ } \\
\text { ウム }\end{array}$ & 燐 & 鉄 & V A & $\mathrm{V} \mathrm{B}_{1}$ & $\mathrm{~V} \mathrm{~B}_{2}$ & V C \\
\hline 均 & 2323 & 80.1 & 42.2 & 5.7 & 491 & 1,565 & 20.7 & 2,551 & 1.55 & 1. 30 & 90 \\
\hline 食品別平均 & 2354 & 76.9 & 41.4 & 388.0 & 531 & 1,369 & 13. 4 & 1,919 & 1. 48 & 1. 26 & 123 \\
\hline
\end{tabular}

中 旬

\begin{tabular}{|c|c|c|c|c|c|c|c|c|c|c|c|}
\hline & 熱 量 & 蛋白質 & 脂 肪 & 含水炭素 & $\begin{array}{l}\text { カルシ } \\
\text { ウム }\end{array}$ & 燐 & 鉄 & V A & $\mathrm{V} \mathrm{B}_{1}$ & $\mathrm{~V} \mathrm{~B}_{2}$ & V C \\
\hline 荷 重 & 2284 & 81.3 & 41.8 & 401.1 & 485 & 1,565 & 21.1 & 2,241 & 1.47 & 1. 35 & 86 \\
\hline 食品別平均 & 2343 & 79.8 & 42.8 & 399.0 & 632 & 1,457 & 14.8 & 1,807 & 1. 46 & 1.32 & 128 \\
\hline
\end{tabular}

下旬

\begin{tabular}{|c|c|c|c|c|c|c|c|c|c|c|c|}
\hline & 熱 量 & 蛋白質 & 脂 肪 & 含水炭素 & $\begin{array}{l}\text { カルシ } \\
\text { ウム }\end{array}$ & 燐 & 鉄 & V A & $\mathrm{V} \mathrm{B}_{1}$ & $\mathrm{VB}_{2}$ & V C \\
\hline 荷 & 228 & 76.0 & 40. & 92.7 & 397 & 1,430 & 28.6 & 2,458 & 1.66 & 1.25 & 92 \\
\hline 食品別平均 & 2316 & 77.2 & 38.8 & 388.4 & 500 & 1,375 & 13. 6 & 1,686 & 1. 47 & 1.14 & 123 \\
\hline
\end{tabular}


上旬

$\begin{array}{lll}\text { 表 } 2 & 7 & \text { 月 }\end{array}$

\begin{tabular}{|l|r|r|r|r|r|r|r|r|r|r|r|}
\hline & 熱 量 & 蛋白質 & 脂 肪 & 含水炭素 & $\begin{array}{l}\text { カル゙ } \\
\text { ヴ }\end{array}$ & 燐 & 鉄 & V A & $\mathrm{V} \mathrm{B} \mathrm{B}_{1}$ & $\mathrm{~V} \mathrm{~B} \mathrm{~B}_{2}$ & $\mathrm{~V} \mathrm{C}$ \\
\hline 荷 重 平 均 & 2254 & 80.0 & 39.5 & 396.4 & 472 & 1,531 & 20.3 & 2,961 & 1.54 & 1.32 & 105 \\
食品別平均 & 2313 & 75.6 & 41.1 & 395.0 & 525 & 1,331 & 13.4 & 2,017 & 1.43 & 1.17 & 132 \\
\hline
\end{tabular}

中 旬

\begin{tabular}{|c|c|c|c|c|c|c|c|c|c|c|c|}
\hline & 熱 量 & 蛋白質 & 脂 肪 & 含水炭素 & $\begin{array}{l}\text { カルシ } \\
\text { ウム }\end{array}$ & 燐 & 鉄 & V A & $\mathrm{V}_{1}$ & $\mathrm{~V} \mathrm{~B}_{2}$ & V C \\
\hline & 23 & 87.1 & 33 & & 487 & 1,468 & 21.9 & 2,157 & 1.58 & 1. 31 & 100 \\
\hline 食品別平均 & 2386 & 81.7 & 38.6 & 412.9 & 486 & 1,445 & 13.1 & 974 & 1. 44 & 1.12 & 101 \\
\hline
\end{tabular}

下旬

\begin{tabular}{|l|r|r|r|r|r|r|r|r|r|r|r|}
\hline & 熱 量 & 蛋白質 & 脂 肪 & 含水炭素 & $\begin{array}{l}\text { カルム } \\
\text { ヴ }\end{array}$ & 燐 & 鉄 & V A & V B $_{1}$ & V B $_{2}$ & V C \\
\hline 荷 重 平均 & 2355 & 83.8 & 41.8 & 404.6 & 477 & 1,586 & 20.7 & 2,261 & 1.57 & 1.31 & 104 \\
食品別平均 & 2411 & 81.0 & 42.4 & 406.0 & 433 & 1,357 & 12.4 & 952 & 1.46 & 1.17 & 99 \\
\hline
\end{tabular}

表 3 月 別計算法 の 比較

6 月平均

\begin{tabular}{|c|c|c|c|c|c|c|c|c|c|c|c|}
\hline & 熱 量 & 蛋白質 & 脂 肪 & 含水炭素 & $\begin{array}{l}\text { カルシ } \\
\text { ウム }\end{array}$ & 燐 & 鉄 & V A & $\mathrm{VB}_{1}$ & $\mathrm{~V}_{2}$ & V C \\
\hline 荷 直 & & & 41 & & 458 & 520 & 3.5 & 2 & 1. & 1. 31 & 8 \\
\hline 食品別平均 & 2338 & 78.0 & 41.0 & 391.8 & 554 & 1,400 & 13.9 & 1,804 & 1. 47 & 1. 24 & 125 \\
\hline
\end{tabular}

7 月平均

\begin{tabular}{|c|c|c|c|c|c|c|c|c|c|c|c|}
\hline & 熱 量 & 蛋白質 & 脂 肪 & 含水炭素 & $\begin{array}{l}\text { カルシ } \\
\text { ウ厶 }\end{array}$ & 燐 & 鉄 & V A & $\mathrm{V} \mathrm{B}_{1}$ & $\mathrm{~V} \mathrm{~B}_{2}$ & V C \\
\hline & & & 38.4 & 2 & 479 & 1, & 21.0 & 2,460 & 1.56 & 1. & 103 \\
\hline 食品別平均 & 2370 & 79.4 & 40. 7 & 404. 6 & 481 & 1,378 & 13. 0 & 1,314 & 1.44 & 1.15 & 111 \\
\hline
\end{tabular}

大豆製品

表4 月 別食品別使用率

\begin{tabular}{|c|c|c|c|}
\hline & 豆 腐 & 油＼cjkstart揚 & その他 \\
\hline 6 月 & 42.2 & 54.4 & 3.4 \\
\hline 7 月 & 34.7 & 65.3 & 0 \\
\hline
\end{tabular}

魚介類

緑黄色野菜類

\begin{tabular}{|c|c|c|c|c|c|c|c|}
\hline & & ホーレン草 & 青菜(小松菜) & 人 & 南 & さやいえげん & $\begin{array}{l}\text { ピーマン } \\
\text { その他 }\end{array}$ \\
\hline 6 & 月 & 18.3 & 33.7 & 16.6 & 5.4 & 13.8 & 12.2 \\
\hline 7 & 月 & 8.1 & 17. 5 & 17. 0 & 18. 5 & 19. 8 & 19.1 \\
\hline
\end{tabular}

$100 \mathrm{~g}$ 当たりの燐は163とむしろ食品別の方が多くな っており, 燐の差鮨類によるものと思われる。

䚧，鯖などは $100 \mathrm{~g}$ 当たり 200

かれい類は " 150

練製品では "

干物類では "

これら定使用率より計算し平均すると $100 \mathrm{~g}$ 当た

\begin{tabular}{|c|c|c|c|c|c|}
\hline & 白身生魚 & 赤身生魚 & 練製品 & 平 均 & 介 類 \\
\hline 6 月 & 41.5 & 38.7 & 8.5 & 9.4 & 1.9 \\
\hline 7 月 & 39.6 & 40.9 & 7.4 & 10.9 & 1.2 \\
\hline
\end{tabular}

1. 2

り200で荷重平均では，346と大変多くなっており燐

の差は，魚類に関係することがわかる。

鉄は生魚では $3 \sim 6$, 大豆製品では豆腐 1.4 , 油掦 4. 2 , 納豆 3.3 亿対し, 荷重平均では, 魚平均が 7.1 ,

大豆製品は 6 といずれも多くなっている。

ビタミンA は荷重平均では, カロチンの量であり

食品別分析表の方は A 効力であるための差と思われ 
る。

ピタミンCは 6 月に差を生じ， 7 月にはほとえぞ 差がなく, 6 月にはホーレン草, 青菜 (小松菜) の 使用\%が緑黄野菜の $52 \%$ 它し， 7 月には，25.6\% と, 半減している。ホーレン草, 青菜は $100 \mathrm{~g}$ 当た り $100 \mathrm{mg}$ に対し, 荷重平均では, $100 \mathrm{~g}$ 当たり $50 \mathrm{mg}$ と食品別の方が多く, 原因はこのホーレン草, 青菜 類にあるととがわかる。

以上のような結果から考元て見ると, この程度の 差では盛付時の多少の差, または調理中の損失, 鮮
度などによっても生じてくるわけであり, 現在の定 員の中で仕事をする以上, 他の業務に支障を来たす よりは, 現在の荷重平均による栄養出納法の方か 1/10 以下の時間ですむととになる。

そこで新潟市病院給食研究会において，第二の段 階として各病院の食糧構成等を調查検討して, 独自 の荷重平均を作成し，簡単で正確な計算のできるよ うに進めて行きたいと考えている。

(本稿第12回日本栄養改善学会において発表し た。)

\section{FAOだより}

\section{F AOグループ， ヨーロッパに家政学会の設立を}

\section{勧告}

〔5月20日 (ローマ)〕本日で $\mathrm{FAO}$ 本部におりる 8 日間の会期を終えた家政改善委員会は, 国際家政 学会を組織する必要のあることを強調した。

この家政改善委員会は, ヨーロッパ農業委員会の 一部に属するものであるが, このたびの委員会は英 国の Florence，F. Laidler 女史を議長として招集 され，副議長にはフランスのFernande. Augié.女 史, 並びにドィッの Hilda. Potthoff 博士が選出 された。

本集会に参加したのは，ローマ教皇庁と同様15力 国の代表者たちであるが，いくつかの非政治団体か らもオブザーバーが出席した。

ここで提案された国際家政学会は、ヨーロッパに 於ける家政学界の人員強化に一助をなすことになる うし，各国の代表が報告したごとく“後日，他の国 々の家政学発展をも助ける”ことになるものと思わ れる。本学会が扱う仕事は, 現在ヨーロッパにおい てその必要性が 痛感されている家政学専門家の養 成, 研究調查, 情報の収集㧍よびその普及などが予 想される。

また，家政学者養成部門の任務の一つとして，消 費者教育に少なからぬ力点を置くよう要請してい
る。なぜならば, ヨーロッパの主婦たちは，地方か ら一時に大量の人口が都市へ流れこえできたり, 多 すぎるほぼ豊富に生産物が市場に出回わった時や急 速に収入が増加した際に゙，どう家計を切り盛りした ら良いのか解っていないからである。

そこで，家政改善委員会は次回の集会で，この問 題について，さらに緻密な検討を加えることに決定 すると共に，将来の委員会にそなえて，各種の社 会, 経济階層別による消費者の要望它調查するよう 政府に勧告している。

ヨーロッパに起とった経済並びに社会的変動は, 家庭生活やその構造を急激に変えてしまった。むろ えヨーロッパにもはが゙かしい発展のみられ效地方 や, 沈滞状態のままの地域が残されてはいるが, 全 般の生活水準は目立ってよくなっている。以上のこ とを認めた上でなお各代表は“豊かな家庭生活を 実現する物質面での改善は，精神的に豊かな家庭生 活を安全に守り育てるための社会的保証と並行して 考虑さるべき性質のものである”ことを指摘してい る。この問題に関する各方面からの研究は, ポトフ 博士の手で準備され, 次の 8 月にアイルランドのダ ブリンで開催される予定の地方社会学問題改善委員 会の集会に提出されることになっている。 